\title{
Penerapan askep pada pasien an. I dengan gastro enteritis akut dalam pemenuhan kebutuhan cairan dan elektrolit
}

\author{
Aslinda
}

Prodi DIII Keperawatan Unisversitas muhammadiyah Makassar

Email : aslindaelly@yahoo.co.id

\begin{abstract}
Abstrak
Diare adalah suatu kondisi dimana seseorang Buang Air Besar dengan konsistensi lembek atau cair, dengan frekuensi lebih dari tiga kali perhari. Di Indonesia Diare merupakan penyakit endemis terdapat disepanjang tahun. Diare merupakan salah satu penyebab utama tingginya kematian anak di dunia akibat komplikasinya yaitu dehidrasi. Tujuan penelitiaan yaitu menggambarkan asuhan Keperawatan pada pasien An"I" dengan Gastro Enteritis Akut dalam pemenuhan kebutuhan Cairan dan Elektrolit. Metode penelitian menggunakan Studi kasus dengan rancangan analisis deskriptif. Dengan pendekatan proses keperawatan terhadap pasien anak gastro enteritis akut (GEA) dalam pemenuhan kebutuhan cairan dan elektrolit. Data yang dikumpulkan dalam penelitian ini menggunakan format pengkajian, format wawancara dan lembar observasi. Hasil penelitian : Setelah dilakukan tindakan keperawatan selama 3x12 jam pada pasien An.I dengan masalah kekurangan volume cairan berhubungan dengan intake dan output yang tidak adekuat telah teratasi. Kesimpulan : Berdasarkan dari hasil tindakan yang dilakukan padaAn. I dapat disimpulkan bahwa masalah kekurangan volume cairan dapat teratasi dengan baik sesuai hasil yang diharapkan.
\end{abstract}

Kata kunci : Asuhan Keperawatan, Cairan Elektrolit, Gastroenteritis Akut.

\begin{abstract}
Diarrhea is a condition where a person defecates with a soft or liquid consistency, with a frequency of more than three times per day. In Indonesia, diarrhea is an endemic disease throughout the year. Diarrhea is one of the main causes of high child mortality in the world due to its complications, namely dehydration. The aim of research is to describe nursing care in patients with "I" with acute gastro enteritis in meeting the needs of fluids and electrolytes. The research method uses a case study with a descriptive analysis design. With a nursing process approach to patients with acute gastro enteritis (GEA) in meeting fluid and electrolyte needs. The data collected in this study used the assessment format, interview format and observation sheet. Results: After nursing measures for $3 x 12$ hours in An.I patients with problems with lack of fluid volume associated with inadequate intake and output were resolved. Conclusion: Based on the results of the actions taken on you. I can conclude that the problem of lack of fluid volume can be resolved properly according to the expected results.
\end{abstract}

Keywords : Nursing care, electrolyte fluid, acute gastroenteritis.

\section{Pendahuluan}

Kematian anak di Indonesia sangat tinggi.Indonesia menduduki rangking ke enam dengan angka kejadian sebesar 6 juta bayi yang mati pertahunnya.Kematian anak dan balita disebabkan oleh penyakit diare, bahkan untuk mendiagnosis diare, maka pemeriksaan antigen secara langsung dari tinja mempunyai nilai sensitifitas mencapai 70-90\% (Joyce, 2014).
Diare merupakan salah satu penyakit endemik di Indonesia terutama Diare Akut. Angka kejadian diare akut disebagian besar wilayahIndonesiahinggasaat ini masih tinggi angka termasuk angka morbiditasdan mortalitasnya. Penyebaran penyakit diare ini juga tersebar kesemua wilayah di Indonesia dengan penderita terbanyak adalah bayi dan balita. Berdasarkan hasil riset kesehatan dasar yang dilakukan oleh Kementrian Kesehatan, Diare Akut merupakan penyebab kematian pada bayi $31,4 \%$ dan balita $25,2 \%$ (Tjitrosusanto, 2013). 
Penyakit diare atau biasa disebut Gastroenteritis, yang masih merupakan masalah masyarakat di Indonesia. Daftar urutan penyebab kunjungan Puskesmas/Balai pengobatan termasuk dalam kelompok 3 penyebab utama ke Puskesmas. Angka kesakitannya adalah sekitar $200-400$ kejadian diare diantara 1000 penduduk setiap tahunnya. Kelompok ini setiap tahunnya mengalami lebih dari satu kali kejadian Diare (Joyce, 2014).

Perawat dalam melaksanakan profesinya berorientasi terhadap pemenuhan kebutuhan dasar manusia. Salah satu kebutuhan dasar manusia yang paling prioritas adalah kebutuhan fisiologi seperti cairan. Cairan dan elekrtolit sangat diperlukan dalam rangka menjaga kondisi tubuh tetap sehat (Saputra, 2013).

Salah satu akibat yang ditimbulkan dari penyakit Diare adalah gangguan volume cairan dan elektrolit. Gangguan volume cairan dan elektrolit merupakan salah satu kebutuhan dasar manusia fisiologis yang harus dipenuhi. Apabila penderita telah banyak mengalami kehilangan cairan dan elektrolit, maka terjadilah gejala dehidrasi. Terutama Diare pada anak perlu mendapatkan penanganan yang cepat dan tepat sehingga tidak mempengaruhi tumbuh kembang anak. Sebagian dari penderita $(1-2 \%)$ akan jatuh kedalam dehidrasi dan kalau tidak segera ditolong 50-60\% diantaranya dapat meninggal (Sodikin, 2012).

Dari kasus diatas penulis tertarik untuk melakukan penelitian tentang penyakit Gastroenteritis Akut (GEA) Pada An.I Dengan Kebutuhan Cairan dan Elektrolit: Kekurangan volume cairan dengan harapan bahwa setelah dilakukannya penelitian maka angka kejadian kasus Gastroenteritis Akut (GEA) dengan gangguan kebutuhan cairan dan elekrolit dapat teratasi khususnya yang terjadi pada anak di RS TK II Pelamonia.

\section{Metode}

Penelitian ini dilakukan di RS TK II Pelamonia pada tanggal 11 s/d 16 Juli 2017, dengan desain penelitian yang digunakan adalah analisis deskriptif dengan pendekatan studi kasus, yaitu penelitian yang berfokus pada suatu kasus tertentu untuk diamati dan dianalisis secara cermat sampai tuntas.

Populasi dalam studi kasus ini adalah semua pasien Anak dengan masalah Gastroenteritis Akut (GEA).Sampel dalam studi kasus ini sesuai dengan kriteris inklusi yaitu pasien anak Gastroenteritis Akut (GEA) yang mengalami gangguan cairan elektrolit yang dirawat di ruang perawatan anak.

Alat pengumpulan data dalam studi kasus ini menggunakan format pengkajian, format wawancara dan lembar observasi.

Analisa data yang dilakukan pada studi kasus ini adalah dengan mendeskripsikan informasi yang telah tersusun dan melakukan penarikan kesimpulan serta pengambilan tindakan.Data yang telah tersusun kemudian disajikan dalam bentuk narasi yang mudah dipahami.

Pengambilan data dan pemberian asuhan keperawatan pada studi kasus ini dilaksanakan setelah mendapatkan imformed consent dari keluarga pasien dan tetap memperhatikan etika penelitian yang meliputi Anonimity (tanpa nama), kerahasiaan (confidentiality), Respect for justice and inclunsinevenes, dan balancing harms and benefits.

\section{Hasil Penelitian}

Berdasarkan hasil pengkajian pada klien didapatkan data, pasien berumur 14 Tahun dengan keluhan utama BAB $5 \mathrm{x}$ sehari sebelum masuk RS. Klien juga mengeluh sakit perut, mual dan pusing. Ibu klien mengatakan bahwa anaknya mulai $\mathrm{BAB}$ sekitar jam 03.00 WITA dengan BAB encer dan ampas. Ibu klien mengatakan bahwa anaknya selalu mengeluh sakit perut setelah 
BAB dan BAK dalam produksi yang sedikit. Ibu klien mengatakan bahwa anaknya malas makan. Setiap hari, anaknya hanya mengkonsumsi indomie telur saja. Ibu klien juga mengatakan bahwa anaknya jarang minum, hanya menghabiskan setengah botol dari air kemasan 1,5 liter sehari. Keadaan umum nampak lemah, mata cekung, konjungtiva pucat, bibir pucat dan kering, turgor kulit jelek, lidah kotor dan akral dingin, BB $30 \mathrm{~kg}$, TB $145 \mathrm{~cm}$, TTV TD :100/70 mmhg, suhu 36,7 derajat C, Nadi $92 \mathrm{x} / \mathrm{i}, \mathrm{P}$ $24 x / i$. dari data yang diperoleh di dapatkan masalah keperawatan dengan diagnosa kekurangan volume cairan berhubungan dengan intake dan output yang tidak adekuat. Perencanaan sesuai masalah keperawatan pada klien yaitu kaji tanda dan gejala dehidrasi (kulit membran mukosa kering, turgor kulit jelek, rasa haus yang berlebihan dll) yang rasionalnya mengetahui tingkat dehidrasi yang dialami. Observasi jumlah asupan dan pengeluaran cairan serta perubahan status keseimbangan cairan yang rasionalnya rehidrasi oral atau parenteral sesuai dengan kebutuhan dapat membantu untuk menjaga keseimbangan cairan dalam tubuh. Pantau tanda-tanda vital dengan rasional takikardi ada sesuai variasi derajat hipotensi, tergantung pada derajat kekurangan cairan. Timbang berat badan anak untuk mengkaji tingkat dehidrasi dengan rasional perubahan $\mathrm{BB}$ tidak secara akurat dapat membantu mengetahui tingkat dehidrasi yang dialami, mempengaruhi volume intravaskuler serta Kolaborasi dengan tim dokter untuk terapi medis dan pemeriksaan laboratorium dengan rasional tergantung pada kesempatan kehilangan cairan, perbedaan ketidakseimbangan cairan mungkin memerlukan perbaikan, misalnya penggunaan larutan glukosa pada pasien dengan intoleran glukosa dapat mengakibatkan peningkatan glukosa serum dan peningkatan kehilangan air urinarius.

Tindakan keperawatan dilaksanakan selama 3 X 24 jam berdasarkan dengan intervensi keperawatan yang telah disusun yaitu Mengkaji tanda dan gejala dehidrasi diperoleh hasil mata cekung, bibir kering dan pucat, klien merasa pusing, nadi cepat dan lemah, Mengobservasi jumlah asupan dan pengeluaran cairan serta perubahan status keseimbangan cairan diperoleh hasil pada saat hari pertama klien hanya menghabiskan setengah dari botol kemasan isi 1,5 liter, Memantau tanda-tanda vital, Menimbang berat badan anak diperoleh hasil BB $30 \mathrm{~kg}$, Kemudian tindakan selanjutnya yang telah dilakukan yaitu mengkolaborasi dengan tim dokter untuk pemberian terapi obat dan pemeriksaan penunjang diperoleh hasil terapi obat yang telah diberikan yaitu pemasangan infus KaEn3B 22 tetes/menit, lacto B 3 X 1 dan Zink kid 1X20 mg, pemeriksaan lab diperoleh RBC 5,75.

Setelah dilakukan tindakan keperawatan, hasil evaluasi dari tindakan yang dilakukan dengan metode SOAP, didapatkan pada hari Selasa tanggal 11 Juli 2017 pukul 14.00 WITA dengan masalah keperawatan kekurangan volume cairan berhubungan dengan intake dan output yang tidak adekuat telah dievaluasi dan didapatkan hasil dari data subjektif, yaitu klien mengatakan sakit perut setelah $\mathrm{BAB}$, ibu klien mengatakan anaknya masih $\mathrm{BAB}$ pada jam $04.001 x$ dan pada pukul 07.00 pagi 1x, dan ibu klien juga mengatakan anaknya masih malas minum. Data objektif di dapatkan Keadaan umum nampak lemah, mata cekung, turgor kulit jelek, bibir kering dan pucat serta nadi cepat dan lemah (90x/i). Assesment yaitu masalah belum teratasi. Planning Lanjutkan Intervensi yaitu kaji tanda dan gejala dehidrasi, pantau jumlah asupan dan pengeluaran cairan serta perubahan status keseimbangan cairan observasi tandatanda vital, dan timbang berat badan anak. Evaluasi dari tindakan pada hari Rabu tanggal 12 Juli 2017 pukul 14.45 WITA dengan masalah keperawatan kekurangan volume cairan berhubungan dengan intake dan output yang tidak adekuat telah dievaluasi dan didapatkan hasil dari data subjektif, yaitu klien mengatakan sakit perut setelah $\mathrm{BAB}$, ibu klien juga mengatakan anaknya masih malas minum. Data objektifdi dapatkan Keadaan umum nampak lemah, mata cekung, 
turgor kulit jelek, bibir kering dan pucat serta nadi cepat dan lemah (92x/i). Assesment yaitu masalah belum teratasi. Planning Lanjutkan Intervensi yaitu kaji tanda dan gejala dehidrasi, pantau jumlah asupan dan pengeluaran cairan serta perubahan status keseimbangan cairan observasi tanda-tanda vital, dan timbang berat badan anak. Evaluasi dari tindakan pada Kamis tanggal 13 Juli 2017 pukul 12.00 WITA dengan masalah keperawatan kekurangan volume cairan berhubungan dengan intake dan output yang tidak adekuat telah dievaluasi dan didapatkan hasil data subjektif ibu klien mengatakan anaknya sudah menghabiskan 1 botol air aqua kemasan 2 liter, ibu klien juga mengatakan bahwa anaknya tinggal $1 x$ BAB yaitu pada pagi hari, klien juga mengatakan bahwa sudah tidak merasa pusing lagi. Data objektif yang didapatkan, yaitu turgor kulit baik, keadaan umum sudah nampak membaik, denyut nadi 86x/menit. Assesment yaitu masalah teratasi. Planning yaitu pertahankan intervensi seperti kaji tanda dan gejala dehidrasi, observasi jumlah asupan cairan dan pengeluaran cairan dalam menjaga keseimbangan cairan yang adekuat, pantau tanda-tanda vital dan timbang berat badan anak.

\section{Pembahasan}

Pembahasan tentang "Penerapan Asuhan Keperawatan pada An"I" dengan Gastroenteritis Akut (GEA) tanggal 11 s/d 16 Juli 2017 dalam Pemenuhan kebutuhan cairan dan elektrolit kurang volume cairan.

Hasil pengkajian pada An'I" didapatkan keadaan umum lemah, BAB 5 kali sebelum masuk RS, Akral dingin,mual muntah,turgor kulit jelek, mata cekung, bibir pucat,Nafsu makan berkurang. Hal ini sejalan dengan data yang akan diperoleh dari Pengkajian menurut Rekawati Susilanigrum dengan gangguan kekurangan volume cairan yakni buang airbesar(BAB)lebihdari3kaliperharidenganko nsistensi cair, Suhu badan meningkat, Nafsu makan berkurang, Akraldingin, Anusdan daerah sekitarnyalecet, Mual muntah,
Keadaan umumlemah, Turgor kulit jelek, Bibir pucatdan kering, Mata cekung.

Pada Diagnosa Keperawatan, diangnosa keperawatan yang muncul pada penyakit Gastro Enteritis Akut menurut Nursalam yaitu Kekurangan volume cairan di tandai dengan Klien nampak lemah, mata cekung, turgor kulit jelek, bibir pucat, peningkatan suhu tubuh kadang terjadi, dan nadi cepat dan lambat, dan diagnosa ini juga didapatkan pada kasus berdasarkan data yang ditemukan yaitu yaitu DS: Ibu klien mengatakan anaknya BAB 5x sehari sebelum masuk RS, klien mengeluh sakit perut setelah BAB dan mual. DO: keadaan umum lemah, konjungtiva pucat, bibir pucat, turgor kulit jelek, TD $100 / 90 \mathrm{mmHg}$, nadi $92 \mathrm{x} / \mathrm{i}$, suhu 36,7 derajat C, pernapasan $24 x / I$, terpasang infus Ka En 3B 22 tetes/menit dibagian lengan kiri.

Pada perencanaan penulis menyusun rencana keperawatan sesuai dengan teori dan studi kasus. Rencana keperawatan dengan tujuan setelah dilakukan tindakan keperawatan selama 3x12 jam, kekurangan volume cairan teratasi dengan kriteria hasil keseimbangan cairan dalam tubuh, hidrasi yang adekuat, asupan makanan dan cairan yang adekuat, BB badan stabil.

Perencanaan yang dibuat berdasarkan diagnosa keperawatan adalah kaji tanda dan gejala dehidrasi (kulit membran mukosa kering, turgor kulit jelek, rasa haus yang berlebihan dll) yang rasionalnya mengetahui tingkat dehidrasi yang dialami. Observasi jumlah asupan dan pengeluaran cairan serta perubahan status keseimbangan cairan yang rasionalnya rehidrasi oral atau parenteral sesuai dengan kebutuhan dapat membantu untuk menjaga keseimbangan cairan dalam tubuh. Pantau tanda-tanda vital dengan rasional takikardi ada sesuai variasi derajat hipotensi, tergantung pada derajat kekurangan cairan. Timbang berat badan anak untuk mengkaji tingkat dehidrasi dengan rasional perubahan BB tidak secara akurat dapat membantu mengetahui tingkat dehidrasi yang dialami, mempengaruhi volume intravaskuler serta Kolaborasi dengan tim dokter untuk 
terapi medis dan pemeriksaan laboratorium dengan rasional tergantung pada kesempatan kehilangan cairan, perbedaan ketidakseimbangan cairan mungkin memerlukan perbaikan, misalnya penggunaan larutan glukosa pada pasien dengan intoleran glukosa dapat mengakibatkan peningkatan glukosa serum dan peningkatan kehilangan air urinarius.

Hasil Implementasi dilakukan berdasarkan intervensi yang telah disusun dari diagnosa yang ditegakkan dalam studi kasus. Semua perencanaaan terlaksana dengan baik tanpa ada kendala karena adanya dukungan dari keluarga dan klien sendiri dalam mengaplikasikan tindakan tersebut.

Evaluasi adalah tahap akhir dari proses keperawatan yang digunakan sebagai titik acuan terhadap tindakan yang telah dilakukan, apakah masalah tersebut teratasi atau tidak teratasi. Evaluasi yang dilakukan setelah melakukan tindakan dengan masalah kekurangan volume cairan, yaitu, Keseimbangan cairan dalam tubuh, hidrasi yang adekuat, cairan yang adekuat, berat badan dalam batas normal.

Dari diagnosa keperawatan yang ditegakkan penulis yang telah dilakukan tindakan keperawatan selama 3 hari di RSTK II Pelamonia dengan klien An.I dengan masalah kekurangan volume cairan berhubungan dengan intake dan output yang tidak adekuat telah dievaluasi dengan menggunakan SOAP dimana S : Ibu klien mengatakan bahwa anaknya sudah menghabiskan botol air aqua kemasan 2 liter, Ibu klien juga mengatakan bahwa anaknya tinggal 1x BAB yaitu pada pagi hari. $\mathrm{O}$ : Keadaan umum nampak membaik, Turgor kulit elastis, Denyut nadi 86x/i. A : Masalah Teratasi. P : Pertahankan Intervensi.

\section{Kesimpulan}

Hasil pengkajian pada pasien An. I dengan Gastro Enteritis Akut (GEA) dalam gangguan pemenuhan kebutuhan cairan yang ditemui di Rumah Sakit keluhan utama BAB 5x sebelum masuk Rumah Sakit disertai sakit perut, mual dan pusing dan akral dingin.

Diagnosa keperawatan utama yang ditegakkan oleh penulis pada An.I adalah Kekurangan volume cairan berhubungan dengan intake dan output yang tidak adekuat.

Rencana Asuhan Keperawatan pada An.I dengan Kekurangan volume cairan berhubungan dengan intake dan output yang tidak adekuat dengan tujuan setelah dilakukan tindakan keperawatan kekurangan volume cairan teratasi dengan kriteria hasil keseimbangan cairan dalam tubuh, hidrasi yang adekuat, asupan makanan dan cairan yang adekuat, BB badan stabil.

Intervensi yang dilakukan berdasarkan diagnose keperawatan pada An"I" dengan masalah kekurangan volume cairan berhubungan intake dan output yang tidak adekuat adalah kaji tanda dan gejala dehidrasi (kulit membran mukosa kering, turgor kulit jelek, rasa haus yang berlebihan, Observasi jumlah asupan dan pengeluaran cairan serta perubahan, status kseimbangan cairan, pantau tanda-tanda vital dengan rasional takikardi ada sesuai variasi derajat hipotensi, tergantung pada derajat kekurangan cairan. Timbang berat badan anak untuk mengkaji tingkat dehidrasi,serta Kolaborasi dengan tim dokter untuk terapi medis dan pemeriksaan laboratorium.

Evaluasi terhadap keberhasilan tindakan yang dilakukan pada An.I dengan hasil evaluasi akhir yaitu terjadi cairan dalam tubuh menjadi seimbang. Masalah tersebut teratasi dengan baik sesuai hasil yang diharapkan dengan menunjukkan kemajuan yang signifikan

\section{Saran}

Di harapkan kepada masyarakat agar dalam pengelolaan pasien anak Gastro Enteritis Akut (GEA) dapat memberikan respon positif sehingga anak memiliki rasa percaya dalam menjalani pengobatan serta memberikan dorongan kepada pasien untuk lebih meningkatkan asupan nutrisi (cairan dan 
makanan) yang dianjurkan dalam mempercepat penyembuhan.

Di harapkan kepada seluruh pengembangan dan tehnologi keperawatan agar lebih memperdalam ilmu dan tehnologi terapan bidang keperawatan, khususnya dalam bidang keperawatan anak agar lebih memperhatikan asupan intake oral pada pasien anak dengan Gastro Enteritis Akut (GEA).

Di harapkan kepada seluruh pengembangan dan tehnologi keperawatan agar semua pasien anak Gastro Enteritis Akut di RS TK II Pelamonia Makassar agar diberikan penyuluhan dan konseling tentang program asupan intake oral agar dapat mempercepat penyembuhan.

Di harapkan agar penulis dapat menambah wawasan dan ilmu pengetahuan serta melakukan penelitian lebih lanjut mengenai Penerapan Asuhan intake oral secara berkala agar pasien mampu memperoleh intake yang adekuat.

\section{Ucapan Terima Kasih}

Kepada Bapak DR. Mustari Bosra, M, Ag selaku ketua Badan Pelaksana Harian (BPH) Akademi Kesehatan Muhammadiyah Makassar, Ibunda Ratna Mahmud S.Kep., Ns., M.Kes, selaku Direktur Akademi Keperawatan Muhammadiyah Makassar, Kepala Ruangan Dahlia RS TK II Pelamonia Makassar beserta seluruh Staff dan semua pihak yang telah memberikan support dan bantuannya yang tidak dapat kami disebutkan satu persatu.

\section{Daftar Pustaka}

JOYCE M. BLACK, J. H. (2014). Keperawatan Medikal Bedah. Salemba Medika.

Nugroho,T.(2013). Asuhan Keperawatan Maternitas, Anak, Bedah, Penyakit Dalam. Yogyakarta:NuhaMedika.
Rekawati Susilaningrum, N.S. (2013). Asuhan Keperawatan Bayi dan Anak. Jakarta:Salemba Medika.

Saputra,L.(2013). Kebutuhan Dasar Manusia. Pamulang-Tangerang Selatan: BINAR UPA AKSARA.

Siswanto, S. S. (2014). Metodologi Penelitian Kesehatan dan Kedokteran .Yogyakarta: BURSA ILMU.

Sodikin. (2012). Keperawatan Anak Gangguan Pencernaan .: EGC. Jakarta,

Wilkison, J. M. (2016). Diagnosis Keperawatan . Jakarta:EGC. 